\title{
Brazilian experience of server behaviour: Perspectives of analysis from sales professionals and customers
}

\author{
Kleber Cavalcanti Nóbrega \\ University Potiguar (UNP) / Laureate International Universities, Brazil \\ Aline Gehlen Rodrigues Silva \\ Federal University of the Northern Great River (UFRN), Brazil \\ Cristine Hermann Nodari \\ University Potiguar (UNP) / Laureate International Universities, Brazil \\ Thereza Angélica Bezerra de Souza Santos \\ University Center of the Great Northern River (UNI-RN), Brazil
}

Keywords

Server Behaviour. Sales. Competitiveness. Sales Professionals. Customers

\begin{abstract}
The research had, as general objective, to evaluate the presence of server behaviour in sales professionals of Brazilian real estate market. It was an exploratory and descriptive work and its universe was composed by real estate agents of the city of Natal, in Rio Grande do Norte - Brazil, being selected a sample of 70 realtors and 135 customers, through the criterion of accessibility. As data collection instruments, two questionnaires were used, both with closed questions, structured and elaborated based on 24 attributes related to the dimensions of server behaviour, considering their importance and their performance in the perception of realtors and customers. With regard to perceptions, divergent results were pointed out, be it with regard to the dimensions of the proposition, or with respect to the attributes. However, the survey found that there are elements of server behaviour in the researched realtors. Also, it was possible to identify the variables and diagnose gaps to be improved to mobilize more competitiveness to these businesses. Finally, limitations and opportunities of future work are presented.
\end{abstract}

Corresponding author: Kleber Cavalcanti Nóbrega

Email addresses for corresponding author: klebercnobrega@gmail.com

First submission received: $5^{\text {th }}$ September 2017

Revised submission received: $10^{\text {th }}$ November 2017

Accepted: $27^{\text {th }}$ November 2017

\section{Introduction}

Global market has undergone changes in trade relations. Increased competition, full access to information from globalization and the opening up of capital made it more difficult to meet customer needs, but rather a factor in the survival of companies (Alperstedt, Martignago, Feuerschütte and Lemos, 2011). Market complexity requires a new sales design as well as a relationship-based marketing philosophy (Kotler and Keller, 2006).

But sales professional was not always given due importance, which, in historical context for a period in which the focus was to sell the product or service without concern for customers, contributed to a negative perception of the profession until now. Conquering and maintaining customers requires qualified professionals who have understanding and practice in business relationships (Alperstedt, Martignago, Feuerschütte and Lemos, 2011). Thus, professionals who design success need to offer more than good products or services, they need to offer superior value for their customers.

In Brazil, professional, administrative and complementary services, according to Brazilian Institute of Geography and Statistics - IBGE (2014), showed an increase in May 2014 of $7.8 \%$, compared to the same month of the previous year, against Growth of 5.2\% in April. As a result, technical-professional services, which cover knowledge-intensive services, grew by $6.7 \%$. According to Grönroos (2007) with the increase in sales volume per year, companies are increasingly oriented towards the market and in recent years, as a strategy for the growth of organizations, have left aside the orientation for product, starting to

www.jbrmr.com A Journal of the Academy of Business and Retail Management (ABRM) 
focus on market, focusing on the need and desire of customers, aiming the "Services". For Fitzsimmons and Fitzsimmons (2005), service orientation is pointed out as an element of competitive differentiation, in which one of the main attributes for managers is to relate the organizational behaviour so that it can add differentiation value to customer, allowing companies to materialize practices to make them a competitive differential.

In real estate market specifically, the high mobility of capital in last decade has transformed the sector into one of the most attractive investments of contemporary capitalism, propitiating expansion of activity, in an environment with little interference from regulatory mechanisms (Queiroz, 1998).

To achieve differentiation, building quality relationships with customers takes place in the way they serve. Relationship-oriented services, as far as customer perceptions of quality, are concerned, propagate and change over time as the relationship continues (Grönroos, 2007). In this context, Nóbrega (2009) refers to performing activities used to serve customer expectations in a servant way. Thus, in the service approach, with focus on the sense of service, the author emphasizes server behaviour and dimensions such as responsibility, simplicity, resignation, initiative, desire to help and good practices. It seems clear to say that they may contribute to a server vendor and are committed to the real needs of customers.

The relevance of research about the behaviour of sales professionals can be seen in Paiva and Melo (2008), who recommend studies that provide new elements for understanding in professionalization processes. From a scientific point of view, there is a lack of studies related to sales professional and there is a gap to be filled in literature. There is an offer of commercial literature and a wide dissemination of theories and techniques in the area of sales, many of them being decontextualized and lacking in scientific depth.

From a practical point of view, the approach, the knowledge of market, as well as the understanding of skills, abilities, technical knowledge and attitudes that promote relationship with customers, depart, in large part in the organizations of these professionals. These represent companies in which they operate, both in external and internal environment, receiving investments and tools to achieve organizational goals. However, "management of the sales force in some companies is still neglected by marketing" (Mcdonald, 2008: 374).

Specifically, about real estate brokers, who are sales professionals, managing and understanding skills and technical knowledge required become relevant to a highly competitive and diverse market, imposing on this sales professional flexibility and expertise in dealing with two customers simultaneously and apparently in a conflict of interest: one to buy and the other to sell.

In view of these considerations, the present study is a problematic aimed at evaluating: how server is the behaviour of sales professionals in the Brazilian real estate market? Among the expected contributions, based on the results, we intend to evaluate the presence of server behaviour characteristics through the skills of sales professionals and how this concept is perceived in service delivery, both by customers as sales professionals in market real estate.

This was an exploratory-descriptive research, with a survey of sales professionals (real estate agents) and customers linked to real estate in the city of Natal, Rio Grande do Norte, Brazil. Multivariate analyses of data were applied in order to identify characteristics of server behaviour in sales professionals.

\section{Sales orientation versus service orientation}

According to Kotler and Keller (2006, p. 138), "customer is the reason for the existence of a company, a source of profit". Therefore, "companies should be geared to serving customer by placing them at the top of organization chart and keeping all sectors focused to meet their expectations" (Zenone, 2010). Customer loyalty, according to Zeithaml, Berry and Parasuraman (1996), positively influences company's profitability, in which satisfied customer is likely to recommend and buy additional services.

Hogan, Lemon and Rust (2002) said that customer-focused companies have decreased communication costs because satisfied customer becomes more indifferent to competitors' actions and promotes future sales by positively indicating the product and brand in their contact circles. In addition, companies must have ethics and commitment to customer, thus strengthening loyalty to the choice of the brand. 
Decomier and Beirn (2003) argue that many salespeople and sales managers are mistaken in believing that manipulation techniques are closely related to sales processes. In fact, realization of sale depends on awareness of urgent needs. In this sense, marketing and sales managers can assist in increasing sales through use of appropriate and timely information, such as innovative reasons for purchase, or strengths and weaknesses of competition.

For Ingram, Laforge and Schwepker (2007), many organizations have used ethics as a key selling point, since many buyers take into account the company's ethical reputation at the time of the purchase decision. According to the author, traditionally, sales organizations have focused on developing, communicating and enforcing laws and codes of ethics to increase ethical behaviour of salespeople.

In addition to ethical commitment and transparency in business relationships, customers demand higher value offerings that can satisfy them and even exceed their expectations. Raising value to customers may provide a long-term relationship with customers (Zenone, 2010). In a comparative study on the ethical profile of marketing professionals and sales professionals, Singhapakdi and Vitell (1992) concluded that in professional practice they tend to value their personal interests more highly. Captivating customer means surprising you as to your expectations. According to Moreira (2001), being honest is one of the simplest ways to captivate customer. For Churchill and Peter (2005: 73), "ethics requires honesty in dealing with customers".

The study conducted by Malshe and Sohi (2009), based on 49 interviews with sales professionals and marketers, indicated that marketing sales consists of four key components: (i) objective and rational persuasion; (ii) sensitivity and responsiveness; (iii) involvement in creative strategies and (iv) positioning for success.

This reality causes organizations to seek greater commitment to their customers (Parvatiyar and Sheth, 1994). With the offer of similar products and services, customer has become the focus of organizations. However, the traditional form of business relationships based on transactions rather than on customers is still the model for many organizations (Madruga, 2010).

For Fitzsimmons and Fitzsimmons (2005), service orientation has been identified as an element of competitive differentiation between companies and organizations, in which one of the manager's main duties is to relate organizational behaviour so that it can add differentiation value to the customers, allowing companies to materialize their practices to make them a competitive differential. According to Grönroos (2007), service orientation should be based on the provision of a wide variety of services added to the core product, be it a tangible asset or an intangible, in order to add value to its competitors with the same quality and price of core products.

However, full knowledge of the characteristics of a particular product or service is not limited to the knowledge of the techniques or attributes, but rather to the benefits that customers can provide. These benefits will be the intangible part. "The tangible part is constituted by the attributes or physical characteristics of the product, being intangible part identified by the symbols or values that the product confers to its possessor" (Cobra, 2001, p.97). This allows us to state that the sales professionals' argument should highlight the solutions and benefits that products or services will bring to customers, redirecting their actions with focus on sales to focus on serving. "A customer does not buy a product for what it is, but for what it does for it" (Grönroos, 2007).

According to surveys by Junior and Campanholo (2013), in the studies of a consulting company and sales training, the techniques and the type of approaches have contributed positively to development of strategic plan of sales of professional consultants. Kotler and Keller (2006) suggest that vendors receive training to learn methods of customer analysis and management. According to Kotler (2000), sales knowledge is essential to obtain results in sales negotiations, since it relies on skills related to prospecting and qualification, pre-approach, approach, presentation and demonstration, overcoming objections, closing and, finally, monitoring and maintenance.

Sales in real estate market are influenced by several macroeconomic factors such as: inflation level, fiscal policies, monetary policies, income, housing plans, foreign investments and according to data from the Federal Council of Realtors (COFECI), real estate market is in constant transformation due to levels of consumer confidence, interest rates charged on financed real estate transactions, GDP growth and variation in per capita income of population (COFECI, 2015). 
In last decades, this transformation occurred through stabilization of economy and reduction of interest rates for housing loans, which facilitated access to the dream of property acquisition. In 2005, according to Advanced Financial Network, when the minimum wage in Brazil was R\$300.00, a family income of at least fifteen minimum wages was required to acquire a property. Currently a family income of only 5 (five) minimum wages is required to acquire a property through real estate credit (ADVFN, 2015). In this sense, as it is a complex activity, investigating real estate market is a challenge that involves specifics of a system that is difficult to understand the reality of a given area, being an important sector of the economy in the world. In addition, the good result of this activity provides development of cities and social groups, generating benefits for industries and consumers that acquire a residential or commercial property (Pereira, 2013).

This development, with the opening of capital and the changing scenery of Brazilian economy in recent decades, attracts investors from several countries. According to a survey carried out in 2012 by Association of Foreign Investors in Real Estate, made up of 200 investment organizations from 21 countries that hold more than US \$ 2 trillion in assets under management globally, Brazil was considered the second best market for real estate investment among and attracting investors to sporting events such as 2014 World Cup and 2016 Olympic Games (AFIRE, 2015).

Despite good prospects and forecasts for the sector, the results were not as expected. In addition to the threat of a real estate bubble, due to the uncertainties of the period - specifically World Cup and presidential elections in 2014 - the developers faced with stagnant stocks and suffered declines in new launches. In this increasingly competitive market, the ability to conduct business requires a high level of professional qualification, and according to the Regional Council of Real Estate Brokers (CRECI), the management of a customer portfolio does not only require traditional sales knowledge. In sales or real estate transactions, it is necessary to analyse and rationally evaluate the most appropriate choice for customers, which will require qualification of that sales professional and deep technical knowledge about his products or services, his company, his competitors and negotiation skills (CRECI, 2014).

Conquering and maintaining customers also requires understanding and practice of relationship marketing and ability to expand market share. Cobra (2001) emphasizes that the traditional vendor does not survive in highly competitive markets, needing to gradually become a business consultant. According to the author, the keyword is relationship, and in a sales advisory activity, it is essential to promote partnerships. These partnerships appear in a variety of roles in negotiation of buying and selling, with some allies, other supporters, as well as business influencers and decision makers, both in commercial transactions in general and in real estate market.

\subsection{Server behaviour and skills of sales professionals}

Server behaviour can be defined as a practice in which the individual is placed in the background and takes initiative to help, doing well to others with useful actions and attitudes related to the dimensions of responsibility, utility, simplicity, resignation, initiative, desire of help and good practices (Nóbrega, 2009).

Orientation for transactional sales is loosing room for relationship orientation in serving. The phenomenon of relationship marketing between the parties (buyer-seller) is considered central and necessary for customers to create value through a good perception of quality (Grönroos, 2007). To that end, Lindgreen (2001) defined relationship-marketing constructs from a broad theoretical review. In corporate sales, Miguel (1995) mentions ways of providing the service in a way that contributes to customer relationship and satisfaction. Friedman (1992), Soldow and Thomas (1993), Stanton and Spiro (2000), Kotler (2000), Levy and Weitz (2000), Moreira (2001) and Castro and Neves (2006) from the customer's approach to monitoring and maintenance.

Parente (2000) and Churchill, Gilbert and Peter (2000) define some basic skills to sell, while studies by Stevens (1989) deal with vendor approaches and characteristics. In a large study, Rabaglio (2001), Rentz, Shepherd, Tashchian, Dabholkar and Ladd (2002) and Durand (2006) emphasize the three dimensions of competence. Morgan (1996) showed traits that annoy and impress customers. Nóbrega (2009), in his studies, addressed server behaviour and its dimensions, while Martins (2010), in a recent research with sales professionals service, identified in his studies attitudes that enable the long-term trust relationship between customers and sales professionals. 
Added to these characteristics of sales professionals are the studies on the skills of realtors, in which several authors point out relevant qualifications of sales professionals in real estate market, based on the Code of Ethics that has regulated this profession since June 1992, Federal Council of Realtors (COFECI, 2015).

Figure 1 summarizes the skills of sales professionals with the relevant skills of the specific market of this study - real estate market. In this way, the dimensions and attributes of the sales behaviour of sales professionals in real estate market have been systematized according to literature review.

\begin{tabular}{|c|c|c|c|}
\hline Dimensions & Attributes & References of Authors & \\
\hline Responsibility & $\begin{array}{l}\text { A1. Have ethics } \\
\text { A2. Have commitment } \\
\text { A3. Have punctuality } \\
\text { A4. Own honesty } \\
\text { A5. Convey interpersonal trust }\end{array}$ & $\begin{array}{l}1,2,19,21 \\
2,4,13,21 \\
2,7 \\
2,7,19,21 \\
1,2,4,13,20,21\end{array}$ & $\begin{array}{ll}1 . & \text { Stevens }(1989) \\
\text { 2. } & \text { Junqueira (1989) } \\
\text { 3. } & \text { Friedman (1992) } \\
\text { 4. } & \text { Spencer e Spencer } \\
& (1993)\end{array}$ \\
\hline Utility & $\begin{array}{l}\text { A6. Have communication / } \\
\text { transparency } \\
\text { A7. Having expertise (knowledge } \\
\text { and practice) } \\
\text { A8. } \\
\text { understanding/understanding Have }\end{array}$ & $\begin{array}{l}1,2,10,11,13,16,21 \\
2,20 \\
2,4,14,16,21\end{array}$ & $\begin{array}{ll}\text { 5. } & \text { Soldow e Thomas } \\
& (1993) \\
\text { 6. } & \text { Miguel (1995) } \\
\text { 7. } & \text { Morgan (1996) } \\
\text { 8. } & \text { Stanton e Spiro } \\
& (2000)\end{array}$ \\
\hline $\begin{array}{l}\text { Practice of } \\
\text { Good }\end{array}$ & $\begin{array}{l}\text { A9. Promote relationship } \\
\text { A10. Offer benefits } \\
\text { A11. Promote similarity }\end{array}$ & $\begin{array}{l}2,3,4,5,8,12,13,15,18,20,21 \\
4,14,16,17,18,20 \\
10,11,13,20\end{array}$ & $\begin{array}{l}\text { 9. Levy e Weitz (2000) } \\
\text { 10. Parente (2000) } \\
\text { 11. Churchill et al }\end{array}$ \\
\hline Renounce & $\begin{array}{l}\text { A12. Minimize conflicts } \\
\text { A13. Possess flexibility (adaptability) }\end{array}$ & $\begin{array}{l}13,20,21 \\
2,10,11\end{array}$ & $\begin{array}{l}(2000) \\
\text { 12. Kotler }(2000) \\
\text { 13. Lindgreen (2001) }\end{array}$ \\
\hline Initiative & $\begin{array}{l}\text { A14. Possess pro-activity/initiative } \\
\text { A15. Possess assertiveness } \\
\text { A16. Search for information/needs }\end{array}$ & $\begin{array}{l}1,2,4,18 \\
2,12 \\
2,4,6,10,11,12,16,18,20,21\end{array}$ & $\begin{array}{l}\text { 14. Rabaglio (2001) } \\
\text { 15. Moreira (2001) } \\
\text { 16. Rentz et al (2002) }\end{array}$ \\
\hline Simplicity & $\begin{array}{l}\text { A17. Do rapport (positive interaction) } \\
\text { A18. Have personality / empathy } \\
\text { A19. Have creativity / imagination }\end{array}$ & $\begin{array}{l}2,13,20 \\
4,18,20 \\
8,12 \\
\end{array}$ & $\begin{array}{l}\text { 18. Castro e Neves } \\
\text { (2006) } \\
\text { 19. Pereira (2009) }\end{array}$ \\
\hline Wish to Help & $\begin{array}{l}\text { A20. Listen carefully } \\
\text { A21. Have patience } \\
\text { A22. Be cooperative } \\
\text { A23. Have guidance in serving } \\
\text { A24. Like people }\end{array}$ & $\begin{array}{l}2,3,10,11,14,16,17,20 \\
1,2 \\
1,4,6,10,11,12,13,14,16 \\
17,18,20 \\
4,10,11,18 \\
1,4,15\end{array}$ & $\begin{array}{l}\text { 20. Martins }(2010) \\
\text { 21. COFECI }(2015)\end{array}$ \\
\hline
\end{tabular}

Figure 1 - Dimensions of server behaviour and attributes of real estate sales professionals

\section{Method}

As for the nature of the study, it has a quantitative and exploratory approach. For Gil (1999), exploratory research has the main purpose of developing, clarifying and modifying concepts and ideas, in order to formulate more precise problems or searchable hypotheses for later studies. The quantitative approach has some characteristics, such as: approaching observation and valuing phenomena, highlighting ideas and showing the degree of reasoning (Marconi and Lakatos, 2010).

Regarding the elements of the server behaviour, these were already identified in the works of Nóbrega (2009). But in terms of attributes, they were constructed based on the relationship between elements of the server behaviour, by Nóbrega (2009), and the skills of real estate sales professionals, according to literature review and the instruments for the empirical research.

A total of 6,500 questionnaires were sent to customers of three real estate companies in the city of Natal, Rio Grande do Norte, obtaining a return of 135 questionnaires. Data collection began in October 2015 ending in January 2016. In relation to the sales professionals (brokers), 70 respondents were compared to a referral of 230 questionnaires. 
After a pre-test with 15 respondents, the research instrument passed the validation test, using a factorial analysis technique. Regarding the reliability of the research instrument, Cronbach's Alpha statistical test was performed, verifying reliability of data. It can be observed that all 24 items evaluated (Importance and performance) by customers and sales professionals, obtained a Cronbach's Alpha oscillating between 0.775 and 0.984 . While the 07 factors evaluated (Importance and performance), a Cronbach's Alpha was obtained, ranging from 0.700 to 0.973 . That is, data consistency is classified as satisfactory in both scenarios.

Likewise, through Bartlett sphericity test, which verified the presence of correlations between variables, a statistical significance of $5 \%$ was found for statistical correlation between the variables studied. The KMO test, which verifies the degree of inter correlations between the variables, generated a value of 0.879 , which implies a good adequacy of the data to the factorial analysis. Based on the eigenvalues, we determine the eigenvectors that constitute the obtaining of the factors and through them we have the linear combination of the original variables, giving rise to factorial loads.

Table 1 shows factorial loads that represent the contribution of each variable to the factor composition. Using Varimax rotation (7 interactions) of the factors to identify the representative factor loads in each factor.

\begin{tabular}{|c|c|c|c|c|c|c|}
\hline Questions & Factor 1 & Factor 2 & Factor 3 & Factor 4 & Factor 5 & Factor 6 \\
\hline Q1 & 0.74 & 0.09 & 0.11 & $\begin{array}{l}-0.07 \\
\end{array}$ & 0.00 & 0.21 \\
\hline Q2 & 0.73 & -0.04 & 0.25 & 0.17 & -0.14 & 0.23 \\
\hline Q3 & 0.64 & 0.36 & 0.00 & 0.17 & 0.27 & 0.02 \\
\hline Q4 & 0.88 & 0.12 & 0.08 & 0.03 & 0.11 & 0.02 \\
\hline Q5 & 0.77 & 0.23 & 0.01 & 0.07 & 0.23 & 0.06 \\
\hline Q6 & 0.68 & 0.33 & 0.02 & 0.11 & 0.30 & 0.07 \\
\hline Q7 & 0.25 & 0.47 & -0.03 & 0.58 & -0.10 & -0.19 \\
\hline Q8 & 0.57 & 0.21 & 0.05 & 0.38 & 0.18 & 0.26 \\
\hline Q9 & 0.34 & 0.30 & 0.08 & 0.15 & 0.13 & 0.56 \\
\hline Q10 & 0.13 & -0.07 & 0.13 & 0.72 & 0.25 & 0.06 \\
\hline Q11 & -0.03 & -0.16 & 0.70 & 0.30 & 0.14 & 0.18 \\
\hline Q12 & -0.05 & 0.10 & 0.43 & 0.62 & -0.05 & 0.28 \\
\hline Q13 & 0.18 & 0.25 & 0.77 & 0.10 & 0.03 & 0.00 \\
\hline Q14 & 0.12 & 0.31 & 0.71 & 0.01 & 0.21 & -0.05 \\
\hline Q15 & 0.29 & 0.19 & 0.31 & 0.05 & 0.65 & 0.06 \\
\hline Q16 & 0.43 & 0.44 & 0.06 & 0.07 & 0.37 & 0.26 \\
\hline Q17 & 0.14 & 0.05 & 0.08 & 0.21 & 0.72 & 0.27 \\
\hline Q18 & 0.23 & 0.21 & 0.07 & 0.01 & 0.14 & 0.74 \\
\hline Q19 & 0.11 & 0.46 & 0.20 & 0.49 & 0.43 & -0.11 \\
\hline Q20 & 0.41 & 0.72 & 0.04 & 0.00 & 0.10 & 0.13 \\
\hline Q21 & 0.14 & 0.79 & 0.12 & 0.08 & 0.05 & 0.27 \\
\hline Q22 & 0.13 & 0.68 & 0.25 & 0.16 & 0.15 & 0.18 \\
\hline Q23 & 0.21 & 0.57 & 0.48 & 0.04 & 0.08 & 0.24 \\
\hline Q24 & 0.08 & 0.20 & 0.07 & 0.47 & 0.14 & 0.45 \\
\hline
\end{tabular}

Table 1 - Factorial loadings in factor composition

Considering the criterion of practical significance, which suggests that factor loads above "0.50" (MINGOTI, 2005: 110), it was possible to highlight the significant variables:

a) Factor 01 represents $35.49 \%$ of variability total of the data set, with the following significant variables: Q1, Q2, Q3, Q4, Q5, Q6 and Q28;

b) Factor 2 that explains $9.88 \%$ of the total variability, we have the compositions of the variables: Q16, Q20, Q21, Q22 and Q23.

c) Factor 3 that explains 6,23\%, we have the compositions of the variables:Q11, Q13 and Q14 
d) Factor 4 (5.41\%), we have the variables: Q7, Q10, Q12, Q19 and Q24.

e) Factor 5, with $4.65 \%$ of total variability being represented by variables Q15 and Q17.

f) Factor 6 with $4.28 \%$ of total variability being represented by variables Q9 and Q18.

The variables Q16, Q19 and Q24 presented a factorial load lower than 0.50 as suggested by the criterion of practical significance, therefore, there was no obligation to keep them in the research instrument. However, within the objective of the study it was decided to continue the questionnaire with the 24 closed questions. Thus, through the factorial analysis, the instrument on the perception of server behaviour in real estate sales professionals in the city of Natal was validated.

The statistical treatment of the data was constructed in Excel format, version 2010, for accomplishment of the descriptive tables and application of statistical tests. Finally, SPSS software, version 20.0 was used to verify the alignment between the rankings and gaps at all times surveyed.

\section{Results}

Regarding the degree of importance, sales professionals pointed out a greater degree of importance to all dimensions surveyed, and considered the three most important dimensions to be Responsibility (9.93), Utility (9.89) and Desire (9.9), the Utility (9.45) and Initiative (9.32). For all dimensions, sales professionals and customers assigned a high degree of importance, the average being evaluated by the sales professionals in (9.51) and the average evaluated by the customers in (9.11).

Regarding the degree of performance, it was observed that the sales professionals pointed out a higher degree of performance in all dimensions compared to the customers. Thus, it is perceived that sales professionals believe to provide a service with a high degree of performance, while the customers indicate an average performance for five dimensions evaluated. For customers, performance of the Utility dimension (7.03) was rated as the best and Good practice (6.03) as the worst performance.

It is observed in Table 2 that customers evaluated the performance of sales professionals as an average performance for the dimensions: Initiative, Desire to Help, Simplicity, Renunciation and Good Practice, and considered a better performance in the dimensions: Utility and Responsibility.

The average evaluated by the sales professionals as to the performance level in the dimensions of the server behaviour was (9.24) while the average performance level evaluated by the customers was (6.64). It should be noted that there is a difference in the average evaluated by the sales professionals and customers as much as the importance as in the performance, being the evaluation by the customers smaller in all dimensions in relation to the sales professionals.

\begin{tabular}{|c|c|c|c|c|c|c|}
\hline \multirow[b]{2}{*}{ Dimension } & \multicolumn{2}{|l|}{ Importance } & \multirow[b]{2}{*}{$P$ - value } & \multicolumn{2}{|c|}{ Performance } & \multirow[b]{2}{*}{$P$ - value } \\
\hline & Customers & $\begin{array}{l}\text { Sales } \\
\text { Professionals }\end{array}$ & & Customers & $\begin{array}{l}\text { Sales } \\
\text { professionals }\end{array}$ & \\
\hline Responsibility & 9.81 & 9.93 & 0.065 & 7.00 & 9.71 & 0.000 \\
\hline Utility & 9.45 & 9.89 & 0.000 & 7.03 & 9.22 & 0.000 \\
\hline Practice of good & 8.41 & 9.08 & 0.000 & 6.03 & 8.67 & 0.000 \\
\hline Renounce & 8.41 & 8.98 & 0.013 & 6.10 & 8.96 & 0.000 \\
\hline Initiative & 9.32 & 9.59 & 0.019 & 6.95 & 9.28 & 0.000 \\
\hline Simplicity & 9.08 & 9.48 & 0.004 & 6.53 & 9.28 & 0.000 \\
\hline Wish to help & 9.30 & 9.60 & 0.012 & 6.83 & 9.53 & 0.000 \\
\hline
\end{tabular}

Table 2 - Comparison of the degree of importance and performance among customers and sales professionals in server behaviour dimensions

As for the degree of importance, it is observed that for sales professionals the attributes A3 - have punctuality (9.97), A6 - have communication (9.94), A8 - have understanding (9.93), A20 - to listen (9.93), A16 - seeking information (9.84), A9 - promoting relationship (9.80) were considered the five most important and have high importance.

While the customers elected the five most important A6 - clear communication (9.78), A3 - to have punctuality (9.73), A20 - listen carefully (9.67), A8 - have understanding (9.53), A15 - have assertiveness (9.37). In this way, both sales professionals and customers agree to evaluate the attributes as highly important. 
Regarding the degree of performance, it was observed that sales professionals showed a higher degree of performance in the attributes A4- have honesty (9.89), A1 - have ethics (9.77), A2 - have commitment (9.74), A20 - listen carefully (9.73) and A3 - have punctuality (9.7). While for the customers, the five attributes that obtained the best performance were A3 - have punctuality (7.24), A7 - have expertise (7.16), A2 - have commitment (7.13), A15 - have assertiveness (7.13), A5 - Convey interpersonal trust (7.07) were the best evaluated performances.

There is a considerable difference between customers and sales professionals regarding performance evaluation, in which sales professionals perceive a higher performance relative to server behaviour, while customers evaluated only five attributes as good performance, and the other attributes with an average performance.

Table 3 shows the 24 attributes evaluated in this study, in which the customers indicated a lower degree of performance and importance than the sales professionals.

\begin{tabular}{|c|c|c|c|c|c|c|}
\hline \multirow[b]{2}{*}{ Attributes } & \multicolumn{2}{|l|}{ Importance } & \multirow[b]{2}{*}{$P$ - value } & \multicolumn{2}{|c|}{ Performance } & \multirow[b]{2}{*}{$P$ - value } \\
\hline & Customers & $\begin{array}{l}\text { Sales } \\
\text { Professionals }\end{array}$ & & Customers & $\begin{array}{l}\text { Sales } \\
\text { Professionals }\end{array}$ & \\
\hline 01 & 9.82 & 9.87 & 0.551 & 6.77 & 9.77 & 0.000 \\
\hline 02 & 9.79 & 9.90 & 0.246 & 7.13 & 9.74 & 0.000 \\
\hline 03 & 9.73 & 9.97 & 0.006 & 7.24 & 9.70 & 0.000 \\
\hline 04 & 9.92 & 9.99 & 0.274 & 6.79 & 9.89 & 0.000 \\
\hline 05 & 9.81 & 9.94 & 0.100 & 7.07 & 9.46 & 0.000 \\
\hline 06 & 9.78 & 9.94 & 0.042 & 7.04 & 9.39 & 0.000 \\
\hline 07 & 9.06 & 9.79 & 0.000 & 7.16 & 8.86 & 0.000 \\
\hline 08 & 9.53 & 9.93 & 0.000 & 6.88 & 9.41 & 0.000 \\
\hline 09 & 9.36 & 9.80 & 0.001 & 6.67 & 9.50 & 0.000 \\
\hline 10 & 8.02 & 9.59 & 0.001 & 6.01 & 9.00 & 0.000 \\
\hline 11 & 7.86 & 7.84 & 0.965 & 5.43 & 7.50 & 0.000 \\
\hline 12 & 7.86 & 8.40 & 0.100 & 5.69 & 8.50 & 0.000 \\
\hline 13 & 8.97 & 9.56 & 0.009 & 6.52 & 9.43 & 0.000 \\
\hline 14 & 9.05 & 9.19 & 0.518 & 6.85 & 9.39 & 0.000 \\
\hline 15 & 9.37 & 9.74 & 0.011 & 7.13 & 9.29 & 0.000 \\
\hline 16 & 9.53 & 9.84 & 0.004 & 6.87 & 9.17 & 0.000 \\
\hline 17 & 9.14 & 9.49 & 0.064 & 6.78 & 9.41 & 0.000 \\
\hline 18 & 9.37 & 9.36 & 0.938 & 6.42 & 9.37 & 0.000 \\
\hline 19 & 8.73 & 9.60 & 0.000 & 6.39 & 9.06 & 0.000 \\
\hline 20 & 9.67 & 9.93 & 0.015 & 6.93 & 9.73 & 0.000 \\
\hline 21 & 9.43 & 9.70 & 0.052 & 6.99 & 9.53 & 0.000 \\
\hline 22 & 9.24 & 9.57 & 0.031 & 6.64 & 9.50 & 0.000 \\
\hline 23 & 9.38 & 9.41 & 0.822 & 6.63 & 9.40 & 0.000 \\
\hline 24 & 8.79 & 9.37 & 0.014 & 6.95 & 9.51 & 0.000 \\
\hline
\end{tabular}

Table 3 - Comparison of attributes regarding the degree of importance and performance between customers and sales professionals

According to the analysis in Table 4, the attributes that were most important for customers and sales professionals in general are: A4 - own honesty (9.94), A5 -convey interpersonal trust (9.86), A1 - have ethics (9.84), A6 - have communication (9.83), A2 - have commitment (9.82), A3 - have punctuality (9.81), A20 listen carefully (9.76), A8 -have understanding (9.66).

\begin{tabular}{llll|ll|ll}
\hline General & & & \multicolumn{2}{l|}{ Customers } & \multicolumn{2}{l}{ Sales professionals } \\
\hline Attributes & Specification & Average & Ranking & Average & Ranking & Average & Ranking \\
\hline $\mathbf{0 4}$ & Own honesty & 9.94 & 01 & 9.92 & 01 & 9.99 & 01 \\
$\mathbf{0 5}$ & Convey interpersonal trust & 9.86 & 02 & 9.81 & 02 & 9.94 & 03 \\
$\mathbf{0 1}$ & Have ethics & 9.84 & 03 & 9.82 & 01 & 9.87 & 06
\end{tabular}

www.jbrmr.com A Journal of the Academy of Business and Retail Management (ABRM) 


\begin{tabular}{|c|c|c|c|c|c|c|c|}
\hline 06 & $\begin{array}{l}\text { Have communication / } \\
\text { transparency }\end{array}$ & 9.83 & 04 & 9.78 & 04 & 9.94 & 03 \\
\hline 02 & Have commitment & 9.82 & 05 & 9.79 & 03 & 9.90 & 05 \\
\hline 03 & Have punctuality & 9.81 & 06 & 9.73 & 05 & 9.97 & 02 \\
\hline 20 & Listen carefully & 9.76 & 07 & 9.67 & 06 & 9.93 & 04 \\
\hline 08 & $\begin{array}{l}\text { Have understanding / } \\
\text { understanding }\end{array}$ & 9.66 & 08 & 9.53 & 07 & 9.93 & 04 \\
\hline 16 & $\begin{array}{l}\text { Search for information / } \\
\text { needs }\end{array}$ & 9.63 & 09 & 9.53 & 07 & 9.84 & 07 \\
\hline 21 & Have patience & 9.52 & 10 & 9.43 & 08 & 9.70 & 11 \\
\hline 09 & Promote relationship & 9.51 & 11 & 9.36 & 11 & 9.80 & 08 \\
\hline 15 & Possess assertiveness & 9.50 & 12 & 9.37 & 10 & 9.74 & 10 \\
\hline 23 & Have guidance in serving & 9.39 & 13 & 9.38 & 09 & 9.41 & 17 \\
\hline 18 & Have personality/empathy & 9.37 & 14 & 9.37 & 10 & 9.36 & 19 \\
\hline 22 & Be cooperative & 9.35 & 15 & 9.24 & 12 & 9.57 & 14 \\
\hline 07 & $\begin{array}{l}\text { Having expertise } \\
\text { (knowledge and practice) }\end{array}$ & 9.31 & 16 & 9.06 & 14 & 9.79 & 09 \\
\hline 17 & $\begin{array}{l}\text { Do rapport (positive } \\
\text { interaction) }\end{array}$ & 9.26 & 17 & 9.14 & 13 & 9.49 & 16 \\
\hline 13 & $\begin{array}{l}\text { Possess flexibility } \\
\text { (adaptability) }\end{array}$ & 9.17 & 18 & 8.97 & 16 & 9.56 & 15 \\
\hline 14 & $\begin{array}{l}\text { Possess pro- } \\
\text { activity/initiative }\end{array}$ & 9.10 & 19 & 9.05 & 15 & 9.19 & 20 \\
\hline 19 & Have creativity/imagination & 9.02 & 20 & 8.73 & 18 & 9.60 & 12 \\
\hline 24 & Like people & 8.99 & 21 & 8.79 & 17 & 9.37 & 18 \\
\hline 10 & Offer benefits & 8.56 & 22 & 8.02 & 19 & 9.59 & 13 \\
\hline 12 & Minimize conflicts & 8.04 & 23 & 7.86 & 20 & 8.40 & 21 \\
\hline 11 & Promote similarity & 7.85 & 24 & 7.86 & 20 & 7.84 & 22 \\
\hline
\end{tabular}

Table 4 - Matrix of importance

It is observed in Table 4 that customers and sales professionals consider important as 3rd attribute (have ethics) and as 8th attribute (have understanding/understanding). However, these attributes do not appear among the 08 most performing attributes.

For customers and real estate sales professionals, honesty, trust, clear communication, commitment, punctuality and careful listening are pointed out as both more important and better performing among the top 08 in the overall ranking.

In relation to the performance matrix, in Table 5, the attributes that obtained the best performance for customers and sales professionals in general are: A3 - have punctuality (8.08), A2 - have commitment (8.02), A5 - Convey interpersonal trust (7.89), A20 - Listen carefully (7.86), A4 - Own honesty (7.85), A6 have communication (7.84), A24 - like people (7.82).

\begin{tabular}{llrc|cccc}
\hline General & & & \multicolumn{2}{c|}{ Customers } & \multicolumn{2}{c}{ Sales professionals } \\
\hline Attributes & Specification & Average & Ranking & Average & Ranking & Average & Ranking \\
\hline $\mathbf{0 3}$ & Have punctuality & 8.08 & 01 & 7.24 & 01 & 9.70 & 05 \\
$\mathbf{0 2}$ & Have commitment & 8.02 & 02 & 7.13 & 03 & 9.74 & 03 \\
$\mathbf{0 5}$ & Convey interpersonal trust & 7.89 & 03 & 7.07 & 04 & 9.46 & 09 \\
$\mathbf{2 0}$ & Listen carefully & 7.88 & 04 & 6.93 & 08 & 9.73 & 04 \\
$\mathbf{1 5}$ & Possess assertiveness & 7.86 & 05 & 7.13 & 03 & 9.29 & 15 \\
$\mathbf{2 1}$ & Have patience & 7.86 & 05 & 6.99 & 06 & 9.53 & 06 \\
$\mathbf{0 4}$ & Own honesty & 7.85 & 06 & 6.79 & 12 & 9.89 & 01 \\
$\mathbf{0 6}$ & Have communication / & 7.84 & 07 & 7.04 & 05 & 9.39 & 13 \\
$\mathbf{2 4}$ & transparency & 7.82 & 08 & 6.95 & 07 & 9.51 & 07
\end{tabular}




\begin{tabular}{|c|c|c|c|c|c|c|c|}
\hline 01 & Have ethics & 7.80 & 09 & 6.77 & 14 & 9.77 & 02 \\
\hline 08 & $\begin{array}{l}\text { Have understanding / } \\
\text { understanding }\end{array}$ & 7.75 & 10 & 6.88 & 09 & 9.41 & 11 \\
\hline 07 & $\begin{array}{l}\text { Having expertise (knowledge and } \\
\text { practice) }\end{array}$ & 7.74 & 11 & 7.16 & 02 & 8.86 & 19 \\
\hline 14 & Possess pro-activity / initiative & 7.72 & 12 & 6.85 & 11 & 9.39 & 13 \\
\hline 17 & Do rapport (positive interaction) & 7.68 & 13 & 6.78 & 13 & 9.41 & 11 \\
\hline 16 & Search for information / needs & 7.66 & 14 & 6.87 & 10 & 9.17 & 16 \\
\hline 09 & Promote relationship & 7.63 & 15 & 6.67 & 15 & 9.50 & 08 \\
\hline 22 & Be cooperative & 7.61 & 16 & 6.64 & 16 & 9.50 & 08 \\
\hline 23 & Have guidance in serving & 7.58 & 17 & 6.63 & 17 & 9.40 & 12 \\
\hline 13 & Possess flexibility (adaptability) & 7.51 & 18 & 6.52 & 18 & 9.43 & 10 \\
\hline 18 & Have personality / empathy & 7.43 & 19 & 6.42 & 18 & 9.37 & 17 \\
\hline 19 & Possessing creativity / imagination & 7.30 & 20 & 6.39 & 19 & 9.06 & 17 \\
\hline 10 & Offer benefits & 7.03 & 21 & 6.01 & 20 & 9.00 & 18 \\
\hline 12 & Minimize conflicts & 6.65 & 22 & 5.69 & 21 & 8.50 & 20 \\
\hline 11 & Promote similarity & 6.14 & 23 & 5.43 & 22 & 7.50 & 21 \\
\hline
\end{tabular}

Table 5 - Performance Matrix

In order to evaluate the correlation of importance and attributed performance ranking, Spearman's non-parametric test with $\boldsymbol{\alpha}=5 \%$ was used, as shown in Table 6.

\begin{tabular}{llll}
\hline Target audience & General & Customers & Sales professionals \\
\hline Importance & & & \\
\hline General & 01 & $0.988^{* *}$ & $0.881^{* *}$ \\
Customers & & 01 & $0.828^{* *}$ \\
Sales professionals & & & 01 \\
\hline Performance & & & $0.897^{* *}$ \\
General & 01 & $0.968^{* *}$ & $0.758^{* *}$ \\
Customers & & 01 & 01 \\
Sales professionals & & &
\end{tabular}

**P-value $<0.01 *$ P-value $<0.05$

Table 6-Spearman test of the 24 attributes in degree of importance and performance

Through Spearman's statistical test, with a significance level of $5 \%$, it is evident that there is a positive correlation between the general level of importance and performance with customers and sales professionals, that is, the two target audiences have similar priorities.

Figure 2 shows differences in attributes among real estate sales professionals, characteristics and recommendations suggested by the matrix. Despite the consumers' evaluation, which considered the performance of real estate sales professionals to be less than importance, it should be emphasized that in the importance matrix and performance of customers and real estate sales professionals, no attribute was classified in quadrant 1Q (definitely improve).

\begin{tabular}{|c|c|c|c|}
\hline \multicolumn{4}{|c|}{ Importance - performance Matrix/ Real estate sales professionals } \\
\hline Region & Attributes & Characteristics & Recommendations \\
\hline 2Q & A7, A10, A9 & $\begin{array}{l}\text { High Importance } \\
\text { Average Performance }\end{array}$ & Improve \\
\hline $3 Q$ & $\begin{array}{l}\text { A1, A2, A3, A4, A5, A6, A8, } \\
\text { A9, A13, A15, A16, A17, } \\
\text { A18,A20, A21, A22, A23, A24 }\end{array}$ & $\begin{array}{l}\text { High importance } \\
\text { High performance }\end{array}$ & Maintain or improve \\
\hline $6 \mathrm{Q}$ & A14 & $\begin{array}{l}\text { High Importance } \\
\text { Average Performance }\end{array}$ & Maintain or reduce \\
\hline $7 \mathrm{Q}$ & A11 & $\begin{array}{l}\text { Low importance } \\
\text { Low performance }\end{array}$ & Maintain \\
\hline
\end{tabular}

www.jbrmr.com A Journal of the Academy of Business and Retail Management (ABRM) 


\begin{tabular}{|c|c|c|c|}
\hline $8 \mathrm{Q}$ & A12 & $\begin{array}{l}\text { Low importance } \\
\text { Average Performance }\end{array}$ & Maintain or reduce \\
\hline \multicolumn{4}{|c|}{ Importance - performance Matrix/Customers } \\
\hline Region & Attributes & Characteristics & Recommendations \\
\hline $2 \mathrm{Q}$ & $\mathrm{A} 18, \mathrm{~A} 22, \mathrm{~A} 23$ & $\begin{array}{l}\text { High Importance } \\
\text { Average Performance }\end{array}$ & Improve \\
\hline $3 \mathrm{Q}$ & 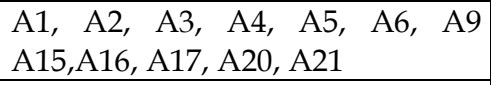 & $\begin{array}{l}\text { High importance } \\
\text { High performance }\end{array}$ & Maintain or improve \\
\hline $5 \mathrm{Q}$ & A13, A19 & $\begin{array}{l}\text { Average Importance } \\
\text { Average Performance }\end{array}$ & Maintain \\
\hline $6 \mathrm{Q}$ & $\mathrm{A} 7, \mathrm{~A} 14, \mathrm{~A} 24$ & $\begin{array}{l}\text { Average Importance } \\
\text { High performance }\end{array}$ & Maintain or reduce \\
\hline $7 \mathrm{Q}$ & A10, A11, A12 & $\begin{array}{l}\text { Low importance } \\
\text { Low performance }\end{array}$ & Maintain \\
\hline
\end{tabular}

Figure 2 - Comparison between importance-performance matrix of real estate sales professionals and the importance-performance matrix of customers

In all 24 attributes evaluated according to the general mean of importance and performance the gaps between importance and performance were negative, in which performance is below the general importance. The attributes with worse performance in relation to importance A4-Own honesty (Gap 2.09), A1-Have ethics (Gap -2.04) and A6- Have communication / transparency (Gap -1.99).

\section{Discussion}

In literature review, according to the authors cited in this study, the characteristics of server behaviour (responsibility, simplicity, resignation, initiative, willingness to help, good and useful practices) are related to organizational behaviour and the sellers' attitudes.

In this research, the responsibility dimension was the best evaluated, followed by the utility dimension. When analysing server behaviour in a Federal Institute of Education, Medeiros (2010) showed that, in evaluation of the dimensions of his study, simplicity was the best evaluated according to the students of that institution. It was verified that the perception of the service provided by the teachers of an educational institution differs in relation to the perception of the service provided by the realtors in this research, since these professionals act in compliance with the code of ethics, which includes standards of responsibility, commitment and ethics with its customers.

The study by Carvalho (2011) evidenced that the server behaviour is similarly perceptible in its degree of importance by three groups analysed in a restaurant chain, with a great emphasis on responsibility, desire to help and utility, similar to the results of our research. In addition, in the research of Medeiros (2010), in a health institution about server behaviour, higher values associated with the element utility were verified, while in the element waiver all the attributes had lower performance in consonance with our research.

In this context, as a competitive differential, the sense of service interferes in human factor for rendering of services provided by sales professionals, adding quality in the perception of clients in relation to the server behaviour as observed in this research.

In Peppers (2012) studies, trust and honesty are considered a competitive advantage in interacting with clients. According to Ferreira (2011), trust is considered by sellers surveyed in their study, as an attribute that positively influences contracts' renewal. When looking at Lindgreen's Relationship Marketing Analytic Model (2001), it can be seen that the attributes listed as the most important attributes by the clients in this research coincide with the constructs necessary for a lasting relationship according to the author.

Through the importance-performance matrix, the attributes that must improve have been showed A7 - Having Expertise, A10 - Offer Benefits, A19 - Possessing creativity, A18 - Have personality, A22 - Be cooperative and A23 - Have guidance in serving. They have become critical because they associate high importance with average performance (figure 2).

As for the performance evaluated in relation to general importance, regarding performance of sales professionals, the gaps were positive for A10, A12, A13, A14, A17, A18, A19, A21, A22, A23 and A24. For the other attributes, the gaps were negative, with performance below importance. Regarding the 
performance of customers in all 24 attributes, the gaps between importance and performance were negative. Which suggests that they should improve as performance is below importance. Regarding the performance of sales professionals, the gaps were positive only for A10, A11, A19 and A24. For the other attributes, the gaps were negative, with performance below the importance.

Morgan (1996) already drew attention in his studies in relation to the lack of preparation and technical knowledge - expertise that can hinder the service of sales professionals. A Perception that this attribute should improve in assessment of real estate sales professionals according to the matrix was identified. In this context, the studies of the same author corroborate the perception of customers who evaluated empathy as an attribute that should improve, followed by cooperation and guidance in serving. Arrogance and antipathy, that is, lack of empathy - ability to put oneself in the other's shoes, are traits that annoy, according to $63 \%$ of the 476 buyers surveyed.

\section{Conclusion}

Sales activity stands out for projecting the image that the company seeks to emphasize in the market, through the communication of salespeople or consultants, who have a relevant role in daily contact with customers and in marketing activities (Las Casas, 2010). With the objective of evaluating the presence of characteristics of the server behaviour through the skills of sales professionals and how customers and sales professionals of real estate market perceive this concept in provision of service, this research revealed important elements about the theme.

As a way of highlighting how server is the behaviour of sales professionals, it was necessary to observe the perception of real estate sales professionals regarding server behaviour of real estate market, the perception of customers and the comparison of their different perceptions regarding the service borrowed. Thus, it can be seen through a field analysis for a selected sample of sales professionals and real estate customers of Rio Grande do Norte that there is server behaviour on the part of the sales professionals of real estate surveyed, since the average of its performance evaluated by the customers was (6.71), considered a good to average performance. It should be noted that this average performance was higher when evaluated by the real estate sales professionals, obtaining (9.31).

Still, it was possible to identify the variables and diagnose the gaps to be improved, which, according to the sales professionals, were: expertise, creativity and benefits. According to the survey, according to customers, real estate sales professionals need to improve the issue of empathy, honesty, and ethics in their performance. In addition, clear and transparent communication, be more cooperative, promote lasting relationships and have guidance in serving. More than negotiating or renting a property, the study points out that customers expect to be served by sales professionals committed to these variables and willing to provide an advisory sale in the real estate market.

The results of this study alerted professionals to the competitive real estate market regarding the difference in perception of real estate sales professionals and customers in relation to the service provided. In addition, it reinforces the need for managerial efforts to qualify these professionals, so as to emphasize the orientation in serving and improving the variables that obtained in the importance-performance matrix, a lower performance in relation to the degree of importance. In addition, the results are conditioned according to the researched sample, being this restricted and characterized as convenience, which requires care for generalizations.

At the same time, it is suggested to carry out new studies on server behaviour in sales professionals, both in real estate market, and in corporate and retail markets. Increased competitiveness requires professionals who are attentive to the differential to win and keep customers - the orientation in serving.

\section{References}

Advanced Financial Network (2015) AFIRE Guide to US Real Estate Investing, available at: http:/ / www.afire.org/ (accessed 17 June 2017).

ADVFN - Advanced Financial Network. Disponível em: <http://br.advfn.com/noticias>. Accessed: 05 fev. 2015.

Alperstedt, G. D., Martignago, G., Feuerschütte, S. G., and Lemos, D. C. (2011), Competencies em vendas no varejo de materiais de construção, Tecnologias de Administração e Contabilidade, Vol. 1, No. 1, pp. 1-13. 
Carvalho, C. T. (2011), Relação entre a orientação para serviço e o senso de servir: o caso de um restaurante comercial [Relationship between service orientation and the sense of service: the case of a commercial restaurant], available at:

https:/ / unp.br/wp-content/uploads/2013/12/dissertacoes-2009-orientacao-para-servico-e-o-senso-de-servircatherine-carvalho1.pdf (accessed 14 May 2017).

Castro, L.T. and Neves, M.F. (2006), O Processo de Vendas [O Processo de Vendas], Atlas, São Paulo, BR.

Conselho Federal dos Corretores de Imóveis (COFECI) (2015), Código de Ética dos Corretores de Imóveis [Real Estate Code of Ethics], Legislação, Brazil.

Churchill, G. A. and Peter, J. (2005), Marketing: criando valor para os customeres [Marketing: Creating Value for Customers], 3rd ed., Saraiva, São Paulo, BR.

Churchill, JR., Gilbert A. and Peter, J. P. (2000), Marketing: criando valor para os customeres [Marketing: Creating Value for Customers] 2nd ed., Saraiva, São Paulo, BR.

Cobra, M. (2001), Serviço aos customeres: uma estratégia competitiva[Service to customers: a competitive strategy],2nd ed., Cobra, São Paulo, BR.

Conselho Regional dos Corretores de Imóveis (CRECI) (2014), Legislaçãoavailable at: http:/ / www.crecimg.gov.br/Legislacao(accessed 10 June 2017).

Decomier, R. A. and Beirn, A. (2003), Corporate policies to include micro activity goals can effect sales urgency in salespeople, prospects and costumers, Industrial and Commercial Trainiing, Vol. 35, No. 5, pp. $220-223$.

Durand, T. (2006). L'alchimie de la compétence, Revue Française de Gestion, Vol. 160, No. 1, pp. 261-292.

Ferreira, E. R. S. (2011) Relacionamento interpessoal entre compradores e vendedores: troca de atendimento em vendas e o impacto na continuidade das relações comerciais. Fundação Getúlio Vargas.

Fitzsimmons, J. andFitzsimmons, M. (2005), Services administration: operations, strategy and information technology,translated by Ritter, R., 4th ed., Bookman, Porto Alegre, BR.

Friedman, H. J. (1992), Não obrigado, estou só olhando [No, thanks, I'm just looking],Papel e Virtual,Rio de Janeiro, BR.

Gil, A. C. (1999), Como elaborar projetos de pesquisa [How to design research projects], 3rd ed., Atlas, São Paulo, BR.

Grönroos, C. (2007), Marketing gerenciamento e serviços [Marketing Management and services] 3rd ed., Elsevier,Rio de Janeiro, BR.

Hogan, J. E., Lemon, K. N. and Rust, R. T. (2002), Customer equity management: charting new directions for the future of marketing, Journal of Service Research, Vol. 5, No. 1, pp. 4-12.

Instituto Brasileiro de Geografia e Estatística (IBGE) (2014), Pesquisa mensal de serviços, IBGE, Brazil.

Ingram, T. N., Laforge, R. W. and Schwepker, Jr. C. H. (2007),Salesperson ethical decision making: the impact of sales leadership and sales management control strategy,Journal of Personal SellingE Sales Management, Vol. 27, No. 4, pp. 301-315.

Junior, J. C. F. andCampanholo, T.(2013),O atendimento no varejo: a busca incansável por um bom atendimento estudo de caso: a empresa sucesso em vendas [Retail service: the tireless pursuit of good service - a case study: the company's success in sales],Consultoria e Treinamento, Vol.4, No.3, pp. 45-60.

Junqueira, G. J.P. (1989), Manual do corretor de imóveis.2nd. ed., Ícone, São Paulo, BR.

Kotler, P. (2000), Administração de marketing, 10th ed., Prentice Hall, São Paulo, BR.

Kotler, P. and Keller, K. L. (2006), Administração de marketing: a bíblia do marketing, 12th ed., Pearson, São Paulo, BR.

Las Casas (2010),Administração de vendas, 8th ed., Atlas,São Paulo, BR.

Levy, M. and Weitz, B. A. (2000), Administração de varejo [Retail Management], 3rd ed., Atlas,São Paulo, BR.

Lindgreen, A. (2001),A framework for studying relationship marketing dyads Quantitative Marketing Research: An International Journal, Vol. 4, No. 2, pp. 75-87.

Madruga, R. (2010). Guia de implementação de marketing de relacionamento e CRM [Relationship Marketing and CRM Implementation Guide], 2nd ed., Atlas São Paulo, BR.

Malshe, A. and Sohi, R. S. (2009), Sales Buy-in of marketing strategies: exploration of its nuances, antecedents, and contextual conditions, Journal of Personal Selling E Sales Management, Vol. 29, No. 3, pp. 207-225.

Marconi, M. A. andLakatos, E. M. (2010), Fundamentos de metodologia científica, 7th ed. Atlas, São Paulo, BR.

Martins, F. A. W. P. and Motta, P. C. M. (2010),Confiança do cliente no vendedor profissional: o que precede este sentimento[Customer trust in professional seller: what precedes this feeling]available at:

https:/ / www.maxwell.vrac.puc-rio.br/16944/16944_1.PDF (accessed 14January 2017).

Mcdonald, M. (2008), Planos de marketing, planejamento em gestão estratégica: como criar e implementar planos eficazes [Marketing Plans, Strategic Management Planning: How to Create and Implement Effective Plans], 6th ed., Elsevier: Rio de Janeiro.

Medeiros, J. C. (2010) Comportamento servidor: o caso do Instituto Federal de Educação, Ciência e Tecnologia do Rio Grande do Norte - IFRN. Universidade Potiguar: Natal, 2010.

Miguel, N.A. (1995),A persuasão na venda pessoal de bens industriais: um modelo pragmático [Persuasion in the personal sale of industrial goods: a pragmatic model] available at: 
http:/ / bibliotecadigital.fgv.br/dspace/bitstream/handle/10438/2480/68488.pdf?sequence=2 (accessed 03May 2017).

Moreira, J. C. T. (2001),Administração de vendas, 2nd ed., Saraiva,São Paulo, BR.

Morgan, G. (1996), Imagens da organização [Images of the organization], Atlas,São Paulo, BR.

Nóbrega, K.C. (2009), Servant Company: how individual behaviour can be expanded to an organizational approach paper presented at thePOMS 20th Annual Conference Orlando, Florida, USA.

Paiva, K.C. M. and Melo, M.C.O.L. (2008), Competências, gestão de competências e profissões: perspectivas de pesquisas, Revista de Administração Contemporânea (RAC), Vol. 12, No. 2, pp. 339-368.

Parvatiyar, A. and Sheth, J. (1994), Relationship marketing: theory, methods and applications. Research Conference proceedings, available at:https://www.jagsheth.com/relationship-marketing/paradigm-shift-in-marketingtheory-approach-the-emergence-of-relationship-marketing/ (accessed 18 June 2017).

Parente, J. (2000), Varejo no Brasil [Retail in Brazil], Atlas, São Paulo, BR.

Peppers, D.; Rogers, M. (2012) Confiança extrema: a honestidade como vantagem competitiva. Elsevier: Rio de Janeiro.

Pereira, A. R. (2009),Responsabilidade civil do corretor de imóveis[Realtor Civil Liability], available at:http:/ / siaibib01.univali.br/pdf/Ricardo\%20Antonio\%20Pereira.pdf(accessed 12 January 2017).

Pereira, F. S. R. (2013). Mercado imobiliário em médias cidades: um estudo da formação, crescimento e influência do mercado de imóveis em Imperatriz/MA, available at:

http://www6.unama.br/ppad/download/dissertacoes/dissert_2013/Dissert_Mestrado_Francisco_Sirdenyo.pdf (accessed 12 May 2017).

Queiroz, L. A. P. C. (1998) Da incorporação ao condomínio fechado: Um estudo sobre as alterações no sistema de produção privada da habitação em Natal/RN. MDU/UFPE. Recife, Brasil.

Rabaglio, M. O. (2001),Seleção por competências. Educator, São Paulo, BR.

Rentz, J.O., Shepherd, D., Tashchian, A., Dabholkar, P. A. and Ladd, R.T. (2002). A measure of selling skill, scale development and validation, Journal of Personal Seling E Sales Management, Vol. 22, No. 1, pp. 13-21.

Singhapakdi, A. and Vitell, S. J. (1992), Marketing ethics: sales professionals versus other marketing professionals, Journal of Personal Selling \& Sales Management, Vol. 12, No. 2, pp.27-38.

Soldow, G. F. and Thomas, G.P. (1993), Vendas: profissionalização para a década de 1990 [Sales: professionalization for the 1990s],Makron Books, São Paulo, BR.Spencer, L.M. and Spencer, S.M. (1993),Competence at work: models for superior performance, John Wiley \& Sons, New York.

Spencer, L.M.; Spencer, S.M. (1993) Competence at work: models for superior performance. John Wiley \& Sons: New York.

Stanton, W.J.; Spiro, R. (2000) Administração de Vendas. 10. ed. LTC, Rio de Janeiro.

Stevens, H.P. (1989), Matching sales skills to customer needs, Management Review, Vol. 78, No. 6, pp. 45-47.

Zeithaml, V. A., Berry, L. and Parasuraman, A. (1996), The Behavioral Consequences of Service Quality, Journal of Marketing, Vol. 60, No. 2, pp. 31- 46.

Zenone, L. C. (2010), Marketing de relacionamento: tecnologia, processos e pessoas [Relationship Marketing: Technology, Processes and People], Atlas, São Paulo, BR. 